\title{
Rhodopsin reconstituted into a planar supported lipid bilayer retains photoactivity after cross-linking polymerization of lipid monomers
}

\author{
Varuni Subramaniam, ${ }^{\ddagger}$ Isabel D. Alves, ${ }^{\dagger}$ Gilmar F. J. Salgado, ${ }^{\dagger}$ Pick-Wei Lau, ${ }^{\dagger}$ Ronald J. Wysocki, Jr., ${ }^{\ddagger}$ \\ Zdzislaw Salamon, ${ }^{\dagger}$ Gordon Tollin,${ }^{\dagger}$ Victor J. Hruby, ${ }^{\dagger \dagger}$ Michael F. Brown,${ }^{\dagger \dagger}$ and S. Scott Saavedra ${ }^{\ddagger *}$ \\ Department of Chemistry and Department of Biochemistry and Molecular Biophysics ${ }^{\dagger}$ \\ University of Arizona, Tucson, Arizona, 85721-0041
}

\section{Supporting information}

\section{Effect of UV irradiation, with and without a bandpass filter, on photoactivity of rhodopsin.}

Rod outer segment (ROS) membranes were isolated from frozen bovine retinas as described previously. ${ }^{1,2}$ The $A_{280} / A_{500}$ absorbance ratio was typically in the range $2.4-2.8$ as determined by solubilizing $50 \mu \mathrm{L}$ of ROS membranes in $150 \mu \mathrm{L}$ of detergent buffer containing $100 \mathrm{mM}$ dodecyltrimethylammonium bromide, $100 \mathrm{mM}$ hydroxylamine, and $15 \mathrm{mM}$ sodium phosphate, $\mathrm{pH}$ 6.9.

Absorbance spectra of solutions of bovine rhodopsin (Rho) in detergent buffer were acquired before and after exposure to light emitted from a low pressure $\mathrm{Hg}$ pen lamp (Figure S1). The lamp output was either unfiltered or passed through a U-330 bandpass filter (Hoya, U-330, $\lambda=330 \pm 80 \mathrm{~nm}$ ) before reaching the sample. This filter blocks the wavelength regime $(>450 \mathrm{~nm})$ which photoactivates Rho. Irradiation without the filter caused the $500 \mathrm{~nm}$ absorbance band to disappear and a second band at $380 \mathrm{~nm}$ to appear,

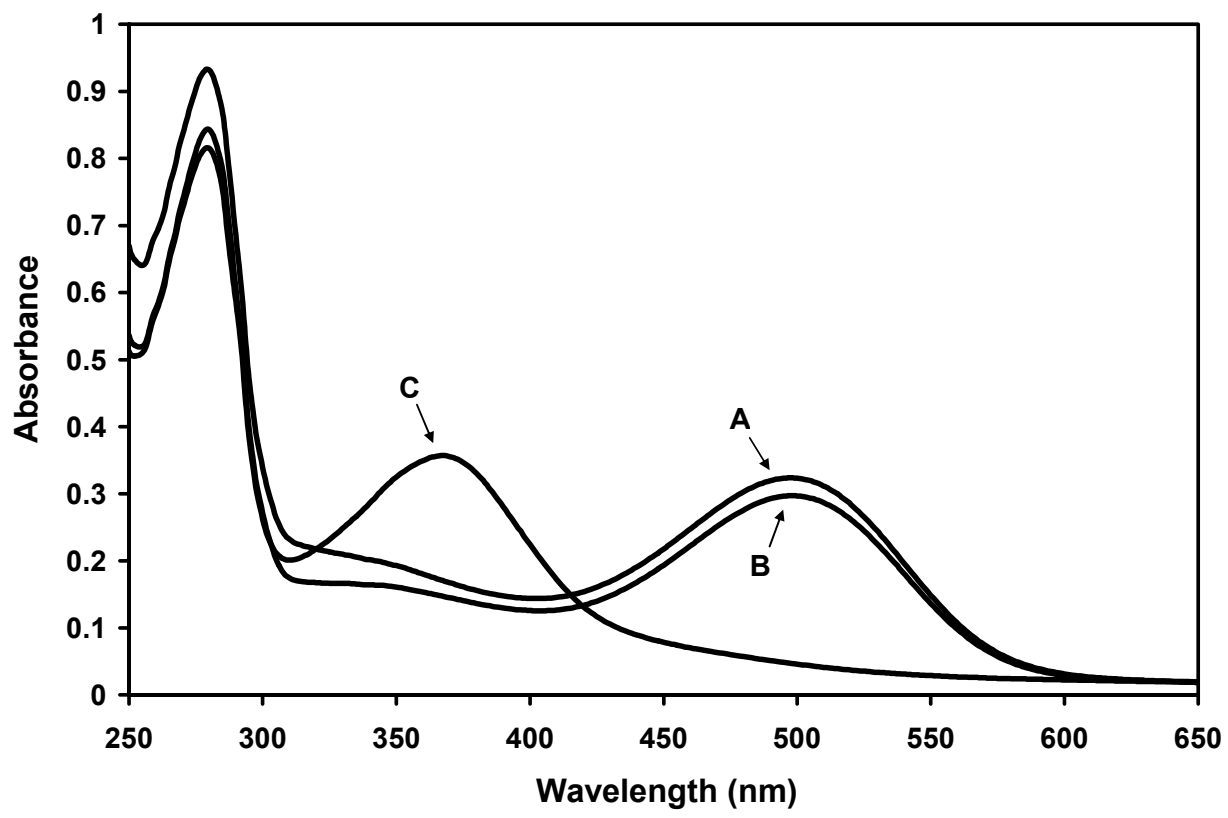

Figure S1. Absorption spectra of Rho ( $3.8 \mu \mathrm{M}$ in $30 \mathrm{mM}$ octylglucoside, $10 \mathrm{mM}$ MES buffer, pH 5.5) acquired before $(\mathrm{A})$ and after $(\mathrm{B}, \mathrm{C})$ exposure to light from a low pressure $\mathrm{Hg}$ pen lamp for $45 \mathrm{~min}$. In curve B, the lamp output was passed through a U-330 bandpass filter prior to the sample, whereas in curve $\mathrm{C}$, no filter was used. 
changes that are characteristic of Rho photolysis to yield the MII intermediate state and/or all-transretinal plus opsin. ${ }^{3}$ Illuminating the sample through the bandpass filter led to a small $(<5 \%)$ reduction in the absorbance at $500 \mathrm{~nm}$, demonstrating that the filter largely blocked photolysis of Rho by the Hg lamp.

\section{Extent of $U V$-initiated polymerization of bis-SorbPC.}

The conditions required to polymerize bis-SorbPC in the PWR cell were determined as follows. The cell was modified by mounting two quartz windows on opposite sides of the aqueous compartment, which allowed absorbance spectra of the solutions to be measured in situ. Small unilamellar vesicles composed of bis-SorbPC prepared by sonication ${ }^{4}$ were injected into the cell. Absorbance spectra (Figure S2) were collected as a function of time that the sample was illuminated with a low pressure $\mathrm{Hg}$ pen lamp through a UG-330 bandpass filter. The extent of monomer to polymer conversion was determined by monitoring the disappearance of the bis-SorbPC monomer, which absorbs at $258 \mathrm{~nm} .{ }^{5,6}$ Illumination for 45 minutes caused the monomer absorbance to decrease by $\geq 95 \%$. An exposure time of 45 min was subsequently used for polymerization of the PSLBs in the PWR cell.

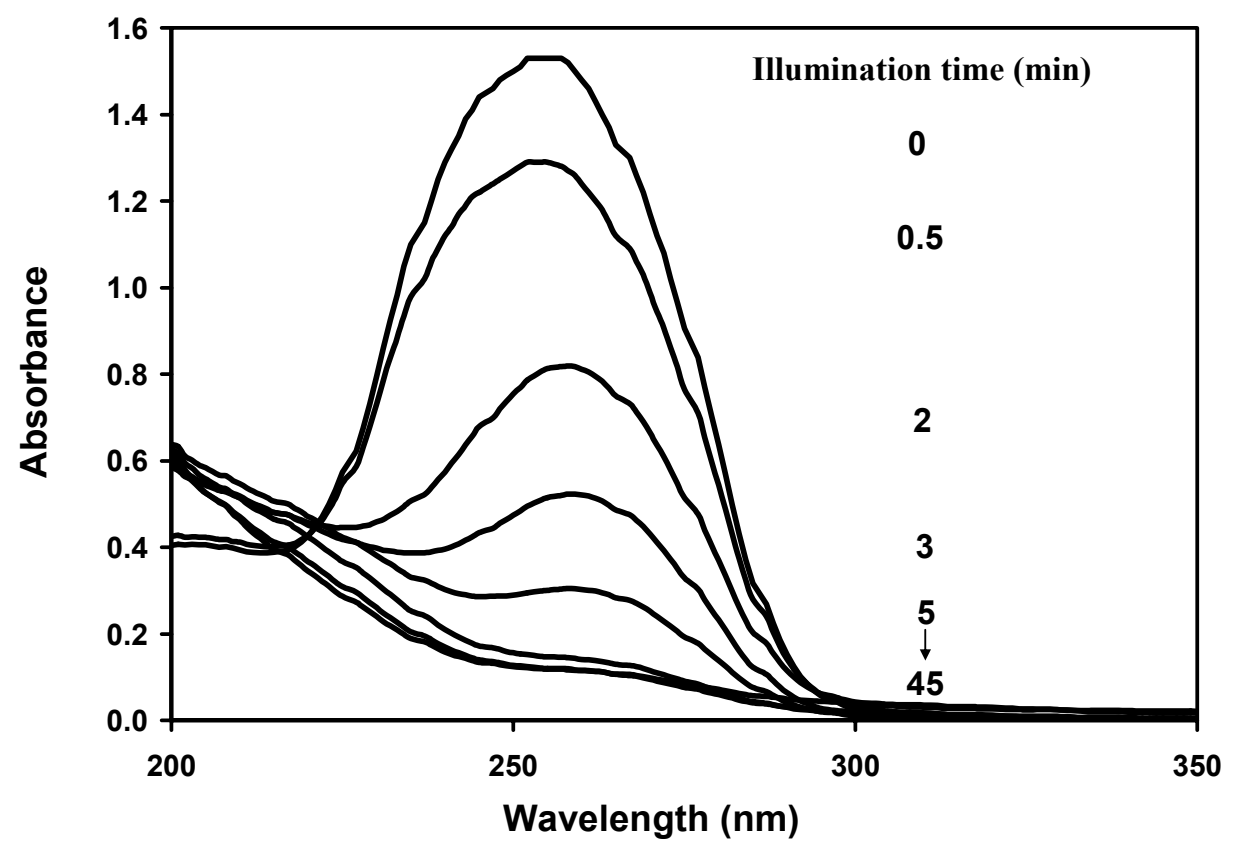

Figure S2: Absorbance spectra of bis-Sorb PC vesicles (lipid concentration $=7 \times 10^{-5} \mathrm{M}$ ) acquired during photopolymerization in the PWR cell, which was filled with $10 \mathrm{mM}$ phosphate buffer $(\mathrm{pH} 6)$. The band at $258 \mathrm{~nm}$ decreased as a function of illumination time, accompanied by an increase in absorbance at wavelengths less than $220 \mathrm{~nm}$. Prior work has established that these spectral changes correspond to bisSorbPC polymerization.,

\section{Stability of PSLBs in the presence of Triton X-100.}

The mechanism of lysis of a lipid bilayer vesicle by a single-chain surfactant is thought to involve incorporation of the surfactant into the bilayer, followed by eventual detachment of mixed micelles composed of surfactant and lipid. ${ }^{7-9}$ Polymerization of lipid bilayer vesicles is known to increase their 
resistance to solubilization by surfactants, and vesicle stability to surfactant solubilization has been used to assess if lipid polymerization has been achieved. ${ }^{10} \mathrm{~A}$ similar strategy was employed here to assess the stability of PSLBs that lacked Rho.

A PSLB composed of bis-SorbPC was formed in the PWR cell and photopolymerized. Aliquots of Triton X-100 solution ( $1 \% \mathrm{v} / \mathrm{v})$ were added to cell, which contained $10 \mathrm{mM}$ phosphate buffer (pH 5.5), and PWR spectra were acquired after each addition. For comparison purposes, this procedure was also performed for PSLBs composed of DOPC and unpolymerized bis-SorbPC; in these cases, the PSLB was not exposed to UV radiation.

The $p$ - and $s$-polarized shifts in the reflectance minima are plotted in Figure S3 as a function of added equivalents $(\mathrm{mol} / \mathrm{mol})$ of Triton X-100. For both DOPC and unpolymerized bis-SorbPC, the initial additions of surfactant caused the reflectance minima to shift to higher angles. This is likely due to insertion of Triton X-100 molecules into the PSLB, resulting in an increase in bilayer mass density.

(a)

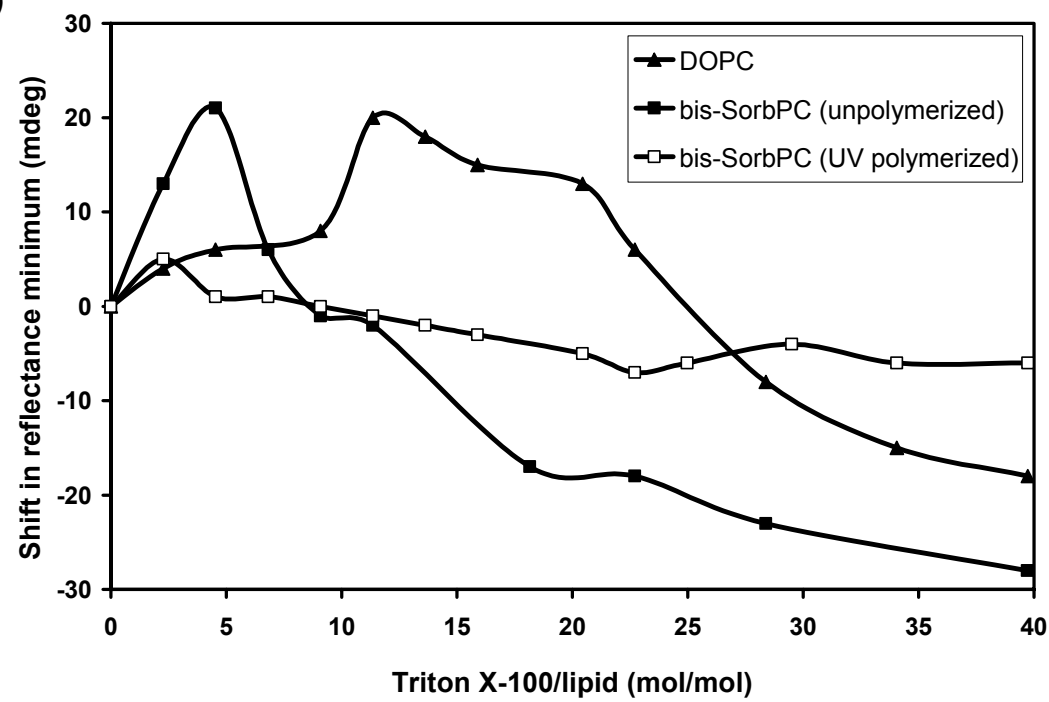

(b)

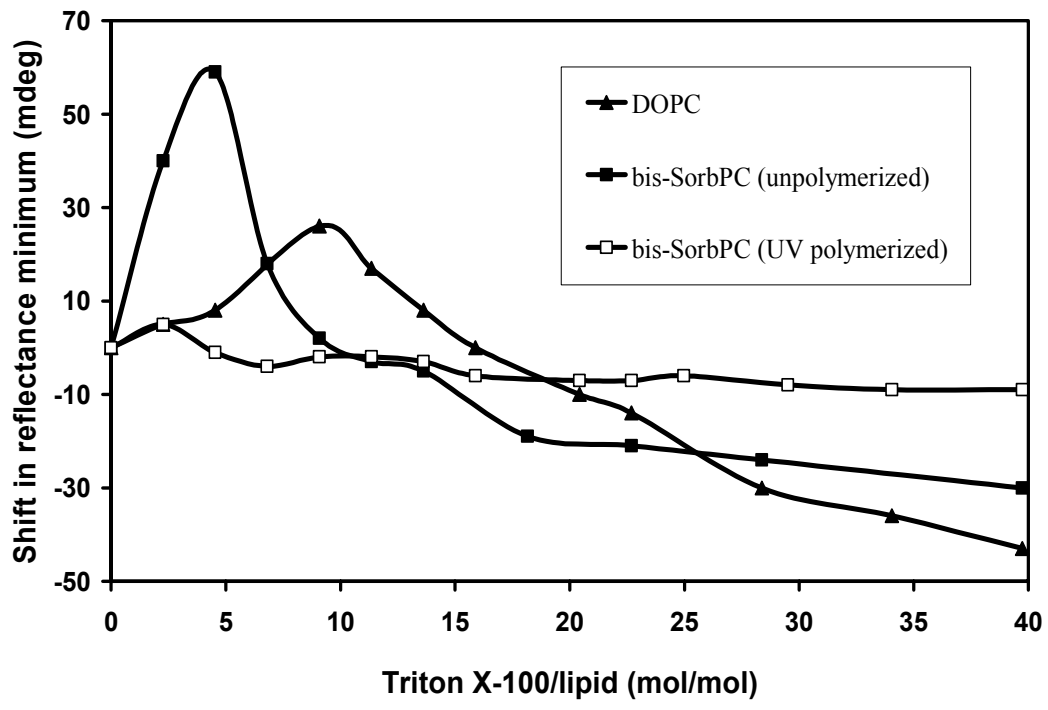

Figure S3. Shifts in PWR reflectance minima for PSLBs composed of DOPC, unpolymerized bisSorbPC, and polymerized bisSorbPC, measured as a function of added equivalents of Triton X-100: (a) $p$-polarized shifts; (b) $s$-polarized shifts. 
Subsequent Triton X-100 additions shifted the reflectance minima to lower angles, corresponding to a decrease in mass density, which is attributed to dissolution of the PSLB. At high values of Triton X100/lipid, the organic film on the $\mathrm{SiO}_{2}$ waveguide surface is probably composed almost entirely of adsorbed Triton X-100.

Very different behavior was observed for polymerized bis-SorbPC. The initial increases in the reflectance minima were much smaller than those observed for the unpolymerized PSLBs, which correspond to a lower degree of surfactant insertion into the poly(lipid). At higher values of Triton X-100/lipid, gradual shifts in the reflectance minima to slightly lower angles were observed. The magnitude of these shifts was significantly less than those observed for the unpolymerized PSLBs. These data show that although Triton X-100 can insert into and structurally alter a poly(bis-SorbPC) PSLB, the degree of disruption is certainly much less than that which occurs with an unpolymerized PSLB. Similar observations have been made for bis-SorbPC vesicles. ${ }^{10}$ In summary, these data (Figures S2 and S3) clearly demonstrate that UV irradiation of a bis-SorbPC PSLB in the PWR cell produces a poly(lipid) bilayer.

\section{Additional PWR data.}

In Figure S4 are shown typical $p$-polarized PWR spectra acquired at each stage of an experiment with poly(bis-SorbPC). Table S1 lists PWR spectral shifts measured in experiments on several types of PSLBs. A comparison of the data listed in the last two lines of Table S1 shows that when Rho is incubated with a bis-SorbPC PSLB that has already been polymerized, less Rho is incorporated relative to an unpolymerized bilayer. Based on the relative magnitudes of the measured PWR shifts $(\{[64 / 100]+$ $[22 / 56]\} / 2=0.5)$, about $50 \%$ less Rho is incorporated into the pre-polymerized PSLB.

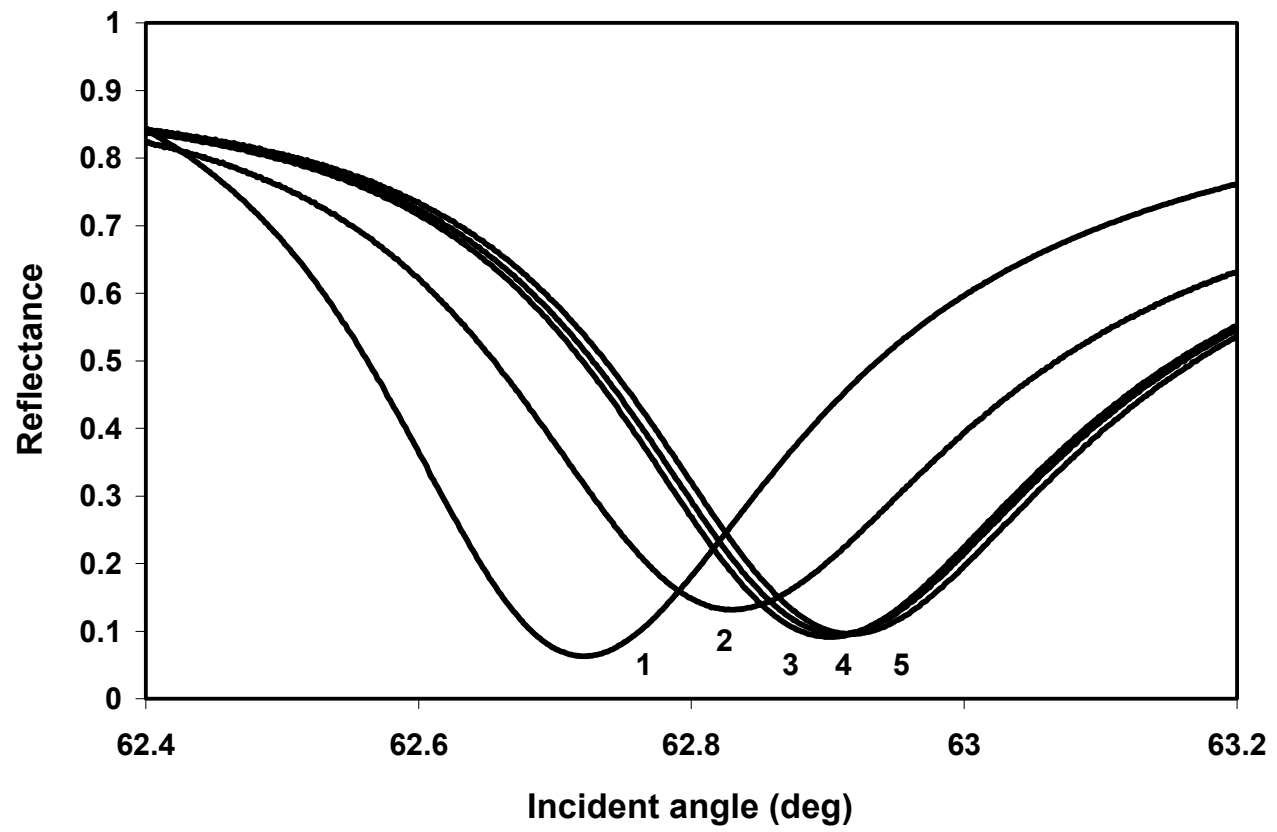

Figure S4. $p$-Polarized PWR spectra: Spectrum obtained with only buffer in the PWR cell (1), after bisSorbPC PSLB formation (2), after Rho incorporation (3), after UV polymerization (4), and after yellow light activation of Rho at $\mathrm{pH} 5.5$ (5). Spectra were acquired with a Beta PWR instrument (Proterion, Piscataway, $\mathrm{NJ})$ at a resolution of $1 \mathrm{mdeg}$ using $632.8 \mathrm{~nm}$ exciting light at ambient temperature $(25 \pm 1$ $\left.{ }^{\circ} \mathrm{C}\right)$. Further experimental details are given in the manuscript and in a previous publication. ${ }^{2}$ 
Table S1. PWR spectral shifts ( $p$ - and $s$-polarized, in + mdeg) due to PSLB formation, Rho incorporation, PSLB polymerization, and yellow light activation at $\mathrm{pH} 5.5$ for different types of lipids.

\begin{tabular}{|c|c|c|c|c|c|c|c|c|}
\hline \multirow[t]{2}{*}{$\begin{array}{l}\text { PSLB } \\
\text { composition }\end{array}$} & \multicolumn{2}{|c|}{$\begin{array}{l}\text { After PSLB } \\
\text { formation }\end{array}$} & \multicolumn{2}{|c|}{$\begin{array}{l}\text { After Rho } \\
\text { incorporation }\end{array}$} & \multicolumn{2}{|c|}{$\begin{array}{l}\text { After UV } \\
\text { polymerization }\end{array}$} & \multicolumn{2}{|c|}{$\begin{array}{l}\text { After yellow light } \\
\text { activation }\end{array}$} \\
\hline & $p$ & $s$ & $p$ & $s$ & $p$ & $s$ & $p$ & $s$ \\
\hline $\mathrm{DOPC}^{\mathrm{a}, \mathrm{b}}$ & 113 & 79 & 70 & 50 & NA & NA & 13 & 8 \\
\hline bis-SorbPC ${ }^{a, b}$ & 116 & 80 & 70 & 51 & NA & NA & 11 & 11 \\
\hline bis-SorbPC ${ }^{\mathrm{a}, \mathrm{b}}$ & 116 & 84 & 78 & 49 & NA & NA & 13 & 11 \\
\hline poly(bis-SorbPC) ${ }^{a}$ & 108 & 73 & 70 & 51 & 4 & 3 & 13 & 12 \\
\hline poly(bis-SorbPC) ${ }^{\mathrm{a}}$ & 110 & 75 & 86 & 52 & 3 & 2 & 15 & 11 \\
\hline poly(bis-SorbPC) $^{\mathrm{c}}$ & 118 & 81 & 100 & 56 & 4 & 3 & 18 & 16 \\
\hline poly(bis-SorbPC) $)^{\mathrm{c}, \mathrm{d}}$ & 119 & 84 & 64 & 22 & 4 & 3 & 7 & 6 \\
\hline
\end{tabular}

${ }^{\mathrm{a}} \mathrm{Rho}$ concentration in PWR cell $=1 \mu \mathrm{M}$. ${ }^{\mathrm{b}} \mathrm{PSLB}$ was not polymerized. ${ }^{\mathrm{c}} \mathrm{Rho}$ concentration in PWR cell $=$ $1.5 \mu \mathrm{M}$. ${ }^{\mathrm{d}} \mathrm{PSLB}$ was polymerized before Rho reconstitution step.

\section{Synthesis of bis-SorbPC $\mathrm{C}_{17,17}$}

bis-SorbPC $\mathrm{C}_{17,17}$ was prepared as published previously. ${ }^{11}$ Essentially the method involves three steps including: monoacylation of 1,10-decanediol ${ }^{12}$ with 2,4-hexadienoyl chloride (sorboyl chloride), ${ }^{13}$ Jones oxidation of the resultant alcohol to the carboxylic acid; and finally, coupling of the carboxylic acid with $s n$-glycero-3-phsophocholine (GPC) cadmium chloride complex ${ }^{12}$ to afford bis- SorbPC $_{17,17}$ as a tan solid. This material is stored in frozen benzene at $-40^{\circ} \mathrm{C}$ at a concentration of $10 \mathrm{mg} / \mathrm{mL}$.

\section{References}

(1) Botelho, A. V.; Gibson, N. J.; Thurmond, R. L.; Wang, Y.; Brown, M. F. Biochemistry 2002, 41, 6354-6368.

(2) Alves, I. D.; Salgado, G. F. J.; Salamon, Z.; Brown, M. F.; Tollin, G.; Hruby, V. J. Biophys. J. 2005, 88, 198-210.

(3) Menon, S. T.; Han, M.; Sakmar, T. P. Physiol. Rev. 2001, 81, 1659-1688.

(4) Ross, E.; Rozanski, L.; Spratt, T.; Liu, S.; O’Brien, D. F.; Saavedra, S. S. Langmuir 2003, 19, 17521765.

(5) Lamparski, H.; O'Brien, D. F. Macromolecules 1995, 28, 1786-1794.

(6) Conboy, J. C.; Liu, S. C.; O'Brien, D. F.; Saavedra, S. S. Biomacromolecules 2003, 4, 841-849.

(7) Lichtenberg, D.; Robson, R. J.; Dennis, E. A. Biochim. Biophys. Acta 1983, 737, 285-304.

(8) Jackson, M. L.; Schmidt, C. F.; Lichtenberg, D.; Litman, B. J.; Albert, A. D. Biochemistry 1982, 21, 4576-4582.

(9) Deo, N.; Somasundaran, P. Langmuir 2003, 19, 7271-7275.

(10) Sisson, T. M.; Lamparski, H. G.; Kölchens, S.; Elyadi, A.; O’Brien, D. F. Macromolecules 1996, 29, 8321-8329.

(11) Lamparski, H.; Liman, U.; Frankel, D. A.; Barry, J. A.; Ramaswami, V.; Brown, M. F.; O'Brien, D. F. Biochemistry 1992, 31, 685-694.

(12) This material is commercially available from Sigma-Aldrich Co.

(13) Macmillan, J. H.; Washburne, S. S. J. Org. Chem. 1973, 38, 2982-2984. 